ISSN: $2548-1843$

\title{
PENGARUH LATIHAN RENTANG PERGERAKAN SENDI TERHADAP \\ KEKUATAN OTOT, LUAS GERAK SENDI DAN KEMAMPUAN \\ FUNGSIONAL PASIEN STROKE DI RS HUSADA JAKARTA
}

\author{
Ni Made Suarti*) \\ Rohani*)
}

*)Dosen Akademi Keperawatan RS Husada, Jakarta, 10730, Indonesia

\begin{abstract}
ABSTRAK
Stroke adalah sindrom klinis akibat gangguan suplai darah ke otak dan mengakibatkan gangguan motorik berupa hemiparese. Tujuan penelitian ini adalah untuk mengidentifikasi pengaruh latihan rentang gerak sendi (RPS) terhadap kekuatan otot, luas gerak sendi (LGS) dan kemampuan fungsional pasien stroke di RS Husada Jakarta. Penelitian ini menggunakan desain penelitian quasi experiment pre dan post test design dengan kelompok kontrol. Jumlah sampel penelitian 30 responden. Teknik pengambilan sampel yaitu consecutive sampling. Analisis statistik yang digunakan yaitu uji t-test independen dan uji t-test dependen. Hasil penelitian menunjukkan kekuatan otot meningkat $(\mathrm{p}=0,000)$ dan kemampuan fungsional meningkat $(\mathrm{p}=0,000)$ secara signifikan setelah diberikan latihan RPS. Kesimpulan penelitian ini adalah latihan RPS berpengaruh terhadap peningkatan kekuatan otot dan kemampuan fungsional. Saran peneliti yaitu perlu dilakukan penelitian lebih lanjut, dan penggunaan latihan ini sebagai intervensi mandiri dalam asuhan keperawatan pasien stroke.
\end{abstract}

Kata kunci : stroke, hemiparese, latihan RPS, kekuatan otot, LGS, kemampuan fungsional.

\begin{abstract}
Stroke is a clinical syndrome caused by blood supply disruption to the brain, it has an effect on many functions of the body. The most obvious motoric deficit effect is hemiparese. The aim of this study is to identify the effect of RPS exercise to muscle strength, joint range of motion and functional ability of patient with stroke at Sint Carolus Hospital Jakarta. A quasi experimental with control group pretest-posttest design was used in this study. The total samples of 30 patients with stroke were selected by a consecutive sampling method. The result showed that muscle strength $(p=0,000)$ and functional ability $(p=0,000)$ were significantly improved after given RPS exercise. This study recommended on the needs of further research, and the use of this exercise as an independent nursing intervention in providing care to stroke patient.
\end{abstract}

Key words : stroke, hemiparese, RPS exercise, muscle strength, joint range of motion, functional ability. 
Pengaruh Latihan Rentang Pergerakan Sendi ...(N.M. Suarti \& Rohani)

\section{Pendahuluan}

Stroke merupakan kondisi abnormal pembuluh darah otak, yang dikarakteristikkan oleh adanya perdarahan di dalam otak atau pembentukan embolus atau thrombus yang menyumbat arteri, mengakibatkan iskemik jaringan otak yang pada kondisi normal diperdarahi oleh pembuluh darah tersebut (Christensen \& Kockrow, 2006). Stroke diklasifikasikan menjadi dua tipe utama, yaitu stroke hemoragik $(85 \%)$ dan stroke non hemoragik (15\%) (Lewis, 2007).

Angka kejadian stroke meningkat seiring dengan pertambahan usia (Siswono, 2001). Data tahun 2007 dari Organisasi Kesehatan Dunia (WHO) menunjukkan bahwa sebanyak 15 juta orang per tahun di seluruh dunia terkena stroke (World Health Report, 2007). Indonesia sendiri merupakan negara dengan jumlah penderita stroke terbesar di Asia dimana stroke merupakan penyakit nomor tiga yang mematikan setelah penyakit jantung dan kanker dan menempati urutan pertama dalam hal penyebab kecacatan fisik (Pdpersi, 2001). Setiap tahunnya diperkirakan
500 ribu penduduk di Indonesia terkena serangan stroke (Yastroki, 2007).

Defisit kemampuan jangka panjang yang paling umum terjadi karena stroke adalah hemiparesis (Lewis, 2007). Hemiparesis merupakan suatu bentuk defisit motorik yang dapat menyebabkan pasien mengalami penurunan mobilitas yang akan mengakibatkan pasien mengalami komplikasi. Hasil penelitian Davenport, Dennis dan Warlow (1994) menemukan bahwa sebanyak $62 \%$ pasien stroke mengalami lebih dari satu tipe komplikasi (American Heart Association/ AHA, 1996). Komplikasi yang dapat terjadi pada pasien stroke diantaranya adalah pembentukan thrombus yang dapat mengakibatkan terjadinya Deep Vein ThRPSbosis (DVT); atrofi otot, jatuh, penurunan fleksibilitas sendi yang dapat mengakibatkan terjadinya kontraktur dan nyeri sendi.

Rentang Pergerakan Sendi (RPS) atau Latihan Range of Motion (ROM) merupakan salah satu bentuk intervensi fundamental perawat yang dapat dilakukan dalam upaya pencegahan terjadinya kondisi cacat 
permanen pada pasien stroke. Lewis (2007) mengemukakan bahwa sebaiknya latihan pada pasien stroke dilakukan beberapa kali dalam sehari untuk mencegah komplikasi.

Rumah Sakit Husada Jakarta merupakan rumah sakit dengan jumlah pasien stroke yang dirawat cukup banyak. Diketahui jumlah pasien stroke hemoragik pada tahun 2006 sebanyak 122 orang dan pasien stroke non hemoragik sebanyak 211 orang. Sedangkan pada tahun 2007, pasien stroke hemoragik dan non hemoragik yang dirawat adalah sebanyak 109 orang dan 239 orang.

Melihat kondisi tingginya angka kejadian stroke, komplikasi yang dapat ditimbulkan, serta peran perawat yang sangat penting dalam upaya pencegahan cacat permanen pada pasien stroke, penulis tertarik untuk melakukan penelitian tentang bagaimana pengaruh latihan RPS terhadap kekuatan otot, luas gerak sendi dan kemampuan fungsional pasien stroke di RS Husada Jakarta.

Tujuan penelitian adalah untuk menjelaskan pengaruh latihan RPS terhadap kekuatan otot, luas gerak sendi dan kemampuan fungsional pasien stroke dan untuk mengetahui apakah faktor-faktor perancu, seperti: usia, jenis kelamin, frekuensi stroke, jenis stroke berhubungan dengan kekuatan otot, luas gerak sendi dan kemampuan fungsional pasien stroke.

\section{Metode}

Penelitian ini menggunakan rancangan quasi experiment pre dan post test design dengan kelompok kontrol (group control), untuk meneliti pengaruh latihan RPS terhadap kekuatan otot, luas gerak sendi dan kemampuan fungsional pada kelompok intervensi dan kelompok kontrol. Total sampel sebanyak 30 responden yang dibagi menjadi kelompok intervensi sebanyak 15 orang pasien stroke yang diberikan penanganan standar rumah sakit dan latihan RPS $4 \mathrm{x}$ sehari selama 7 hari; dan kelompok kontrol sebanyak 15 orang pasien stroke yang hanya diberikan penanganan standar rumah sakit. Penilaian kekuatan otot, luas gerak sendi dan kemampuan fungsional responden dilakukan pada hari pertama dan ketujuh untuk kedua kelompok responden. Populasi dalam penelitian ini adalah seluruh pasien stroke rawat inap yang mengalami 
hemiparese di Husada Jakarta pada bulan Februari 2017. Teknik pengambilan sampel yaitu consecutive sampling. Analisis statistik yang digunakan yaitu uji t-test independent, t-test dependen dan General Linear Model.

Alat pengumpulan data yang digunakan adalah format pengkajian karakteristik responden; format penilaian kekuatan otot, luas gerak sendi dan kemampuan fungsional; goniometer; skala kekuatan otot dan Index Barthel.

Analisis yang digunakan pada penelitian adalah analisis univariat dari karakteristik responden, rerata kekuatan otot, rerata luas gerak sendi dan rerata kemampuan fungsional pasien stroke. Analisis bivariat dengan uji $t$-test independen dan $t$-test dependen digunakan untuk mengetahui pengaruh latihan RPS terhadap kekuatan otot, luas gerak sendi dan kemampuan fungsional. Analisis multivariat dengan uji General Linear Model untuk mengetahui hubungan faktor perancu (usia, jenis kelamin, frekuensi stroke, jenis stroke) dengan kekuatan otot, luas gerak sendi dan kemampuan fungsional.

\section{Hasil}

Analisis dilakukan menggunakan analusis univariat dan bivariat

Tabel 1

Distribusi Responden Berdasarkan Umur pasien Stroke di RS Husada, Februari 2017 $(n=30)$

\begin{tabular}{cccccc}
\hline $\begin{array}{c}\text { Jenis } \\
\text { Kelompok }\end{array}$ & N & Mean & SD & $\begin{array}{c}\text { Min- } \\
\text { Mak }\end{array}$ & 95\% CI \\
\hline Intervensi & 15 & 56,27 & 11,7 & $25-74$ & $49,8-62,7$ \\
\hline Kontrol & 15 & 64,27 & 11,1 & $43-85$ & $58,1-70,4$ \\
\hline
\end{tabular}

Rerata umur responden adalah 60,27. Usia termuda dari seluruh responden adalah 25 tahun $(3,33 \%)$ dan umur tertua adalah 85 tahun. Responden terbanyak berumur antara 41-65 tahun yaitu sebanyak 20 orang $(66,7 \%)$.

Tabel 2

Distribusi Responden Berdasarkan Jenis Kelamin, Frekuensi Stroke dan Jenis Stroke pasien Stroke di RS Husada, Februari $2017(n=30)$

\begin{tabular}{|c|c|c|}
\hline Variabel & $\mathbf{N}$ & Persentase \\
\hline \multicolumn{3}{|l|}{ 1. Jenis Kelamin: } \\
\hline Laki-laki & 16 & $53 \%$ \\
\hline Perempuan & 14 & $47 \%$ \\
\hline \multicolumn{3}{|l|}{ 2. Frekuensi Stroke : } \\
\hline Serangan pertama & 22 & $73 \%$ \\
\hline Serangan & 8 & $27 \%$ \\
\hline kedua/lebih & & \\
\hline \multicolumn{3}{|l|}{ 3. Jenis stroke: } \\
\hline Stroke hemoragik & 22 & $73 \%$ \\
\hline $\begin{array}{l}\text { Stroke non } \\
\text { hemoragik }\end{array}$ & 8 & $27 \%$ \\
\hline
\end{tabular}


Hasil penelitian diperoleh pasien lakilaki berjumlah 16 orang $(53,3 \%)$ sedangkan perempuan sebanyak 14 orang $(46,7 \%)$. Hasil penelitian ini sesuai dengan teori yang mengungkapkan bahwa serangan stroke lebih banyak terjadi pada lakilaki dibandingkan perempuan (Lewis, 2007).

Tabel 3

Distribusi rerata kekuatan otot dan kemampuan fungsional pasien Stroke di RS Husada, Februari $2017(n=30)$

\begin{tabular}{ccccccc}
\hline Variabel & $\begin{array}{c}\text { Jenis } \\
\text { Kelp. }\end{array}$ & $\begin{array}{c}\text { Mea } \\
\mathbf{n}\end{array}$ & $\begin{array}{c}\text { Medi } \\
\text { an }\end{array}$ & SD & $\begin{array}{c}\text { Min } \\
-\end{array}$ & $\mathbf{9 5 \%}$ CI \\
& & & & & Mak & \\
\hline Kuat otot & Intervensi & 2,93 & 3 & 0,88 & $1-4$ & $2,4-3,4$ \\
sebelum & kontrol & 2,2 & 2 & 1,32 & $1-4$ & $1,5-2,9$ \\
\hline Kuat otot & Intervensi & 4,2 & 5 & 1,01 & $2-5$ & $3,6-4,8$ \\
sesudah & Kontrol & 2,13 & 2 & 1,25 & $1-4$ & $1,4-2,8$ \\
\hline Fungsion & Intervensi & 66 & 60 & 23,7 & $30-$ & $52,8-$ \\
al & Kontrol & 57,3 & 60 & 18,6 & 95 & 79,1 \\
sebelum & & & & & $20-$ & $47,0-$ \\
& & & & & 95 & 67,6 \\
\hline Fungsion & Intervensi & 84,3 & 85 & 17,2 & $50-$ & $74,8-$ \\
al & kontrol & 61,67 & 60 & 17,8 & 100 & 93,9 \\
sesudah & & & & & $20-$ & $51,8-$ \\
& & & & & 95 & 71,5 \\
\hline
\end{tabular}

Rata-rata kekuatan otot meningkat antara sebelum intervensi $(2,93)$ dan sesudah intervensi (4,2). Tidak terdapat adanya perbedaan yang signifikan rata-rata kekuatan otot antara responden yang berumur $<60$ tahun dengan responden yang berumur > 60 tahun. Diketahui juga bahwa tidak ada perbedaan rata-rata kekuatan otot antara responden yang mengalami serangan pertama dengan responden yang mengalami serangan kedua atau lebih dan tidak ditemukan pula adanya perbedaan rata-rata kekuatan otot antara stroke non hemorhagik dengan stroke hemorhagik. Diketahui sebelumnya dari penelitian yang dilakukan Kwakkel, G., dkk (1997) yang menemukan bahwa ada hubungan yang signifikan antara intensitas rehabilitasi terhadap efek rehabilitasi yang terlihat pada pasien setelah serangan stroke (AHA, 1997).

\section{Tabel 4}

Distribusi rerata luas gerak sendi pasien Stroke di RS Husada, Februari 2017 (n=30)

\begin{tabular}{cccccc}
\hline Variabel & $\begin{array}{c}\text { Jenis } \\
\text { Kelp. }\end{array}$ & $\begin{array}{c}\text { Waktu } \\
\text { ukur }\end{array}$ & $\begin{array}{c}\text { LGS } \\
\text { <normal }\end{array}$ & $\begin{array}{c}\text { LGS } \\
\text { normal }\end{array}$ & $\%$ \\
\hline Bahu & Intervensi & Sebelum & 2 & 13 & 50 \\
$\left(180^{\circ}\right)$ & & Sesudah & 2 & 13 & 50 \\
& Kontrol & Sebelum & 4 & 11 & 50 \\
& & sesudah & 4 & 11 & 50 \\
\hline Pangkal & Intervensi & Sebelum & 2 & 13 & 50 \\
paha & & Sesudah & 2 & 13 & 50 \\
$\left(180^{\circ}\right)$ & \multirow{2}{*}{ Kontrol } & Sebelum & 3 & 12 & 50 \\
& & sesudah & 3 & 12 & 50 \\
\hline Lutut & Intervensi & Sebelum & 0 & 15 & 50 \\
$\left(120^{\circ}\right)$ & & Sesudah & 0 & 15 & 50 \\
& \multirow{2}{*}{ Kontrol } & Sebelum & 0 & 15 & 50 \\
& & sesudah & 0 & 15 & 50 \\
\hline
\end{tabular}

Mayoritas responden dalam penelitian ini menunjukkan nilai luas gerak sendi yang normal. Artinya bahwa sebagian besar responden tidak mengalami penurunan fleksibilitas sendi yang mungkin diakibatkan karena imobilisasi ekstremitas yang mengalami hemiparese. Secara konsep dikatakan bahwa atrofi otot 
dan kontraktur sendi sekunder karena kurangnya aktivitas dapat berkembang dalam 1bulan setelah terjadi serangan stroke (Lewis, 2007).

Latihan RPS dikatakan dapat mencegah terjadinya penurunan fleksibilitas sendi dan kekakuan sendi (Lewis, 2007). Pernyataan ini sejalan dengan penelitian yang dilakukan oleh Tseng C.N., Chen C.C., Wu, S.C., \& Lin, L.C. (dalam Journal Advanced Nursing, 2007) yang mengungkapkan bahwa latihan RPS dapat meningkatkan fleksibilitas dan luas gerak sendi pada pasien stroke.

Sebanyak $20 \%$ dari total responden mengalami shoulder hand syndrome pada ekstremitas yang mengalami kelemahan. Diketahui dari penelitian sebelumnya yang dilakukan Depkes RI bahwa sebanyak $27 \%$ pasien stroke mengalami shoulder hand syndrome (Depkes RI, 2004).

Tabel 5

Distribusi perbedaan rerata kekuatan otot dan kemampuan fungsional sebelum dan sesudah intervensi di RS Husada, Februari $2017 \quad(n=30)$

Penelitian ini menunjukkan bahwa nilai kekuatan otot pada kelompok yang dilakukan intervensi berbeda dengan kekuatan otot pada kelompok yang tidak dilakukan intervensi. Hal ini terlihat dari nilai $p$ value $=0,000(\alpha=0,05)$. Hal ini berarti bahwa latihan RPS berpengaruh terhadap peningkatan kekuatan otot pasien stroke.

\section{Pembahasan}

Angka kejadian stroke meningkat seiring pertambahan umur (Lewis, 2007). Risiko terkena stroke meningkat sejak usia 45 tahun. Setelah mencapai 50 tahun, setiap penambahan usia tiga tahun meningkatkan risiko stroke sebesar 11-20\%, dengan peningkatan bertambah seiring usia (Feigin, 2006).

Penelitian yang dilakukan oleh Survei ASNA di 28 rumah sakit seluruh Indonesia mengungkapkan bahwa dari profil umur pasien stroke didapatkan hasiqlubahwa profil usia dibawah 45

\begin{tabular}{|c|c|c|c|c|c|c|}
\hline \multirow{5}{*}{$\begin{array}{l}\text { Kuat } \\
\text { otot }\end{array}$} & & $\mathbf{S}$ & & $\mathbf{n}$ & & hasiłlubahwa profil usia dibawah 45 \\
\hline & Inter & Sebelum & 15 & 2,93 & 0,9 & $02=0000$ - \\
\hline & Vensi & & 15 & 4,2 & 1,0 & 0,3 tahun cukup banyak yaitu $11,8 \%$, \\
\hline & Kontrol & & 15 & 2,2 & 1,3 & $0,3 \quad 0.334$ \\
\hline & & Sesudah & 15 & 2,13 & 1,3 & $0,345-61$ tahun berjumlah $54,2 \%$, d \\
\hline \multirow{4}{*}{$\begin{array}{c}\text { Fung } \\
\mathrm{si}\end{array}$} & Intervensi & Sebelum & 15 & 66 & 23,7 & \\
\hline & & & & 84 , & 17,2 & 65 tahun $33,5 \%$ \\
\hline & Kontrol & & 15 & 57,3 & 18,6 & \\
\hline & & Sesudah & 15 & 61,6 & 17,8 & 4,6Misbach, 2007). \\
\hline
\end{tabular}


Usia termuda responden adalah 25 tahun sebanyak 1 orang. Secara teori, hampir 4\% kejadian stroke terjadi pada orang berusia antara 15 dan 40 tahun (Feigin, 2007). Pada kasus ini, responden tersebut memiliki riwayat stroke dan hipertensi dalam keluarga (orang tua kandung).

Riwayat stroke dalam keluarga, terutama jika dua atau lebih anggota keluarga pernah mengalami stroke pada usia kurang dari 65 tahun, dapat pula meningkatkan risiko terkena stroke (Feigin, 2006).

Sesudah pasien mendapatkan latihan RPS 4x sehari selama 7 hari, terdapat manfaat untuk pasien, yaitu adanya peningkatan kekuatan otot dan kemampuan fungsional. Selain itu, latihan RPS juga dapat mencegah terjadinya komplikasi seperti kontraktur dan atrofi otot.

Penelitian yang mendukung hasil penelitian ini adalah hasil Survei ASNA yang dilakukan di Indonesia (1995) dimana menunjukkan bahwa penderita laki-laki lebih banyak daripada perempuan (Misbach, dalam Manajemen Stroke Secara Komprehensif, 2007), yaitu laki-laki $238(57 \%)$ dan perempuan 117 (43\%).
Frekuensi serangan stroke terbanyak adalah serangan stroke pertama sebanyak $73 \%$. Hasil penelitian ini sejalan dengan survei statistik yang dilakukan di Amerika Serikat yang mengungkapkan bahwa tiap tahun kurang lebih 700 ribu orang di Amerika mengalami stroke. Dari jumlah itu, sekitar 500 ribu merupakan serangan pertama dan 200 ribu merupakan serangan stroke berulang (U.S. Centers for Disease Control and Prevention dan the Heart Disease and Stroke Statistics, 2007).

Jenis stroke terbanyak adalah stroke non hemoragik (73\%). Stroke hemoragik merupakan jenis stroke dengan jumlah kejadian kurang lebih $15 \%$ dari seluruh kejadian stroke. Walaupun angka kejadiannya relatif kecil tetapi jenis stroke ini memiliki tingkat kematian 2 sampai 6 kali lebih besar dibandingkan stroke iskemik (Hickey, 2003).

Pada analisis multivariat, ditemukan bahwa faktor perancu : usia, jenis kelamin, frekuensi dan jenis stroke tidak berhubungan dengan kekuatan otot. Secara konsep dikatakan bahwa pemulihan ekstremitas lebih banyak ditentukan oleh pemulihan fungsional 
jaringan otak, ada tidaknya penyakit penyerta yang menghambat peningkatan kekuatan otot dan intensitas rehabilitasi. Walaupun di konsep yang lain menyatakan bahwa waktu pemulihan jaringan otak bergantung pada jenis stroke dan umur pasien.

Rata- rata kemampuan fungsional sebelum intervensi pada kelompok intervensi adalah 66,00 dan rata-rata kemampuan fungsional sesudah intervensi adalah 84,33. Hal ini berarti bahwa rata-rata kemampuan fungsional meningkat setelah dilakukan latihan RPS. Rata-rata kemampuan fungsional meningkat, baik pada kelompok intervensi maupun kelompok kontrol. Penelitian sebelumnya yang dilakukan oleh Tseng C.N., Chen C.C., Wu, S.C., \& Lin, L.C. (dalam Journal Advanced Nursing, 2007) mengungkapkan bahwa latihan RPS dapat meningkatkan kemampuan fungsi aktivitas pasien stroke.

Hasil penelitian menunjukkan bahwa rata-rata kemampuan fungsional pasien stroke meningkat sesudah dilakukan latihan RPS, baik pada kelompok intervensi maupun pada kelompok kontrol. Meskipun rata-rata peningkatan kemampuan fungsional pada kelompok kontrol lebih kecil dibandingkan rata-rata peningkatan kemampuan fungsional pada kelompok intervensi.

Penelitian ini juga mengungkapkan bahwa baik itu latihan RPS yang dilakukan 4x sehari maupun latihan RPS yang diberikan hanya 1x sehari sama-sama berpengaruh terhadap peningkatan kemampuan fungsional. Hal ini terlihat dari nilai $p$ value $=0,000 \quad(\alpha=0,05) . \quad$ Hasil penelitian ini sejalan dengan hasil penelitian yang dilakukan oleh Tseng, C.N., dkk (dalam Journal Advanced Nursing, 2007) yang mengungkapkan bahwa latihan RPS dapat meningkatkan kemampuan aktivitas pasien stroke.

Dalam analisis multivariat, ditemukan bahwa variabel perancu : umur, frekuensi dan jenis stroke tidak berhubungan dengan kemampuan fungsional. Namun jenis kelamin berhubungan dengan kemampuan fungsional. Hal ini dapat disebabkan oleh distribusi responden berdasarkan jenis kelamin yang tidak merata antara kelompok intervensi dan 
kelompok kontrol. Dalam penelitian ini, mayoritas laki-laki lebih banyak di dalam kelompok intervensi dan mayoritas perempuan lebih banyak di dalam kelompok kontrol.

\section{Kesimpulan}

Latihan RPS berpengaruh terhadap peningkatan kekuatan otot dan kemampuan fungsional. Melihat hasil yang bermanfaat dalam penelitian ini untuk pasien stroke, asuhan keperawatan pasien stroke harus mencakup latihan RPS yang merupakan salah satu intervensi mandiri keperawatan. Pelaksanaan latihan RPS dapat dilakukan lebih dari 1x sehari oleh perawat tanpa harus disediakan tempat khusus atau tambahan biaya bagi pasien.

\section{Daftar Pustaka}

Anonim. (2007). Unit stroke : manajemen stroke secara komprehensif. Editor : Rasyid, A.,dr.,SpS \& Soertidewi, L.,dr.,SpS(K).,M.Epid. Jakarta : Balai Penerbit FKUI

Anonim. (1999). Modul (MA 2600) biostatistik \& statistik kesehatan. Editor : Sabri, L. \& Hastono, S.P. Depok : Program Pasca Sarjana
Program Studi IKM Universitas Indonesia (untuk kalangan sendiri).

Christensen, B.L., \& Kockrow, E.O. (2006). Foundations and adult health nursing. $5^{\text {th }}$ edition. St. Louis Missouri : Mosby Elsevier.

Davenport,R.J., $\quad$ Dennis,M.S., Wellwood,I., \& Warlow,C.P.(1999).

Complications after acut stroke. http://stroke.ahajournal.org/cgi/co ntent/full/27/3/415, diperoleh tanggal 13 Februari 2016.

Depkes RI. (2004). Standar pelayanan unit stroke. Jakarta : Depkes RI.

Feigin, V. (2006). Stroke : panduan bergambar tentang pencegahan dan pemulihan stroke. Cetakan ketiga. Alih bahasa: Brahm Udumbara. Jakarta : PT. Bhuana Ilmu Populer.

Hickey, J.V. (2003). The clinical practice : neurological and neurosurgical nursing. $5^{\text {th }}$ edition. Philadelphia : Lippincott Williams \& Wilkins.

Kwakkel, G., Wagenaar, R.C., Koelman, T.W., Lankhorst, G.J., \& Koetsier, J.C.(1997). Effects of Intensity of Rehabilitation After Stroke.

http://www.stroke.ahajournals.org, diperoleh tanggal 9 Juli 2016.

Lewis (2007). Medical surgical nursing. $7^{\text {th }}$ edition. St.Louis : Missouri. Mosby-Year Book, Inc.

Pdpersi (2001). Stroke, penyebab utama kecacatan 
fisik.http://pdpersi.co.id/?show=de tailnews\&kode $=6438$ tbl $=$ cakrawal a, diperoleh tanggal 4 Februari 2016.

Ranakusuma.(2007). Stroke mengintai pengidap diabetes. http://republika.com, diperoleh tanggal 4 Februari 2016.

Siswono (2001). "Stroke", si pembunuh nomor satu. http://www.fullnews.cgi.htm, diperoleh tanggal 4 Februari 2016.

Smeltzer, S.C., \& Bare, B.G. (2002). Brunner \& Suddarth : Textbook of medical surgical nursing. Philadelphia : Lippincott Williams \& Wilkins.
Tseng, C.N., Chen, C.C., Wu, S.C., \& Lin, L.C.(2007). Effects of a range-of-motion exercise programme.

http://www.ncbi.nlm.nih.gov, diperoleh tanggal 9 Juli 2016.

World Health Report (2007). Stroke statistics.

http://www.strokecenter.org/patie nts/stat.htm, diperoleh tanggal 12 Februari 2016.

Yastroki. (2007). Indonesia, negara dengan jumlah penderita stroke terbesar di Asia. http://www.yastroki.or.id/read.php ?id=319, diperoleh tanggal 5 Februari

2016. 